\title{
MAQUIAVEL, PENSADOR TRÁGICO
}

\author{
Jean Castro da Costa
}

é professor de Teoria Política do Departamento de Sociologia e Ciência Política da Universidade

Federal de Santa Catarina (UFSC). Florianópolis, SC, Brasil. jeancastrocosta@gmail.com

Orcid: 0000-0002-4629-6615

http://dx.doi.org/10.1590/0102-127168/107

\section{Introdução}

Em 21 de outubro de 1525 Maquiavel assinou uma carta ao seu amigo Guicciardini como "Nicolau Maquiavel, historiador, cômico e trágico" (Machiavelli, 1971, p. 1224). Na ocasião, ele estava concluindo sua História de Florença e já havia escrito comédias e seus mais importantes textos políticos, mas nunca escrevera tragédias. Por que Maquiavel teria incluído o termo "trágico" na caracterização que fez de si mesmo? Ridolfi (2003) comenta que nesta carta Maquiavel lamentava o fracasso do plano de expulsão dos espanhóis de Milão, ao qual ele havia se dedicado. Entretanto, diante deste resultado negativo, o seu comentário na mesma carta foi algo cômico, pois Maquiavel conclama a "fazer um bom carnaval", com a encenação de sua comédia Clizia. Como notou Ridolfi, "sua vis tragica está inteiramente contida nessa prosa breve" (Ridolfi, 2003, p. 249), pois, diante de um grave revés, a reação do florentino não foi de tristeza e acusação contra a vida, mas de preparação para que "façamos um bom carnaval". O trágico e o cômico aparecem entrelaçados nessa atitude afirmativa de Maquiavel. A visão trágica de mundo a que me refiro aqui envolve uma determinada 
visão sobre o cosmos e sobre o homem, acompanhada de uma postura afirmativa frente aos limites negativos que fazem parte da condição humana.

Na Grécia antiga o senso comum era "trágico" e os filósofos, com poucas exceções, foram antitrágicos. ${ }^{1}$ Nos tempos modernos, as visões trágicas de mundo surgem em contextos nos quais certos pressupostos centrais da visão judaico-cristã entram em crise, e, ao mesmo tempo, ocorre uma intensificação do contato com as obras dos antigos gregos e romanos. Mais que isso, os antigos são pensados em termos próprios e vistos como sendo dignos de serem imitados. Nessa recuperação, revelam-se tensões entre as heranças clássica ("pagã”) e judaico-cristã da cultura ocidental e surgem as visões trágicas de mundo e as filosofias do trágico. Isso ocorreu sobretudo na Renascença italiana e entre os alemães, entre meados do século XVIII e fins do XIX, contexto intelectual fortemente marcado pelo "amor aos gregos" e pela tentativa de imitá-los (Kaufmann, 1968; Machado, 2006). Neste artigo, entendemos o trágico principalmente pela perspectiva de Nietzsche, para quem trágico (ou dionisíaco) é aquele que considera que "sobre todas as coisas está o céu Acaso, o céu Inocência, o céu Contingência” (Nietzsche, 2011, p. 158), que tudo o que existe está em devir permanente, por meio de jogos e conflitos entre forças. Além disso, trágico é aquele que afirma a vida nessa realidade, na sua inteireza, tanto na alegria quanto no sofrimento. Trágico é quem "diz Sim à vida mesmo nos seus problemas mais duros e estranhos". Como afirmativo, o trágico é "o mais extremo oposto e antípoda de um filósofo pessimista” (Nietzsche, 2008, p. 61). Portanto, a

\footnotetext{
1 A visão trágica de mundo estava presente no senso comum e nas obras de poetas e historiadores antigos. A filosofia, em contraste, foi predominantemente "antitrágica" em vários sentidos, por exemplo, na sua tentativa de apagar o acaso e o devir sem finalidade: "A história da filosofia ocidental abre-se por uma constatação de luto: a desaparição das noções de acaso, de desordem, de caos. Disso é testemunha a palavra de Anaxágoras: 'no começo era o caos; depois vem a inteligência, que arruma tudo'” (Rosset, 1989, p. 13). Ver também: Deleuze, 2001, p. 38; Kahn, 1979; Nietzsche, 1992, p. 142.
} 
visão trágica envolve uma hipótese descritiva sobre o mundo e uma determinada atitude diante dele.

Apesar das diferenças entre os pensadores trágicos, é possível delimitar alguns elementos comuns das visões trágicas de mundo, que de modo sumário são: 1) O Ser é Caos, ou melhor, uma sucessão de ordens casuais e precárias (Caosmos) ;2 2) O devir incessante é movido por conflitos entre forças e não há reconciliação final nem fim da história; 3) Nossa capacidade de conhecer existe, mas é limitada pelo acaso inerente ao real e pela nossa própria perspectiva; 4) Não existe apenas uma concepção de Bem que possa ser derivada desta ordem trágica do cosmos, mas várias são possíveis e elas nem sempre são compatíveis (politeísmo de valores, pluralismo) $;^{3} 5$ ) Os trágicos defendem uma atitude afirmativa, trágica e cômica, frente aos Caosmos e aos limites da condição humana. A afirmação trágica nega o puro fatalismo e aposta na agência humana como sendo capaz de realizar grandes feitos neste mundo, ainda que o agente não tenha pleno controle sobre si mesmo (agência não soberana) nem das circunstâncias que antecedem e que decorrem de suas ações (caráter trágico da ação). Nesta concepção, as ações ocorrem no terreno da incerteza e nem os criadores nem as suas obras escapam ao devir e também desaparecerão no seu tempo (mortalidade). Mesmo neste caso, é possível a afirmação cômica, que ri dos seus próprios limites e fracassos e até mesmo da queda dos seus próprios "mestres da finalidade

\footnotetext{
2 "A dimensão política da tragédia decorre antes de mais nada e acima de tudo de sua base ontológica. O que a tragédia traz à vista de todos - não 'discursivamente', mas por apresentação - é que o Ser é Caos. O Caos apresenta-se aqui, primeiramente, como a ausência de ordem para o homem, a falta de correspondência positiva entre as intenções e as ações humanas, por um lado, e seus resultados e consequências, por outro. Mais que isso, a tragédia mostra não apenas que não somos senhores das consequências de nossos atos, mas também que não dominamos nem mesmo a sua significação. O Caos também se apresenta como Caos no homem, isto é, como sua hubris (Castoriadis, 2002, p. 316).

${ }^{3}$ Isaiah Berlin destacou que Maquiavel e Nietzsche eram críticos do cristianismo e admiradores da moralidade pagã, e que ambos descobriram que há "incompatibilidade de valores últimos", quer dizer, ambos seriam "pluralistas", no sentido do "politeísmo de valores" (Berlin, 2002, p. 317, 341).
} 
da existência”. ${ }^{4}$ Neste sentido, Maquiavel poderia ser considerado um pensador trágico?

\section{Fontes do trágico na Florença de Maquiavel}

As fontes para a visão trágica de Maquiavel encontram-se no acesso que ele teve ao teatro trágico (grego e romano) e às obras de escritores antigos (especialmente poetas, historiadores e filósofos atomistas). Seu contato com o teatro trágico foi bem documentado por comentadores ligados à crítica literária e não há dúvida de que Maquiavel leu tragédias latinas e, provavelmente, também algumas gregas, seja nas traduções para o latim feitas pelos colegas e amigos que se reuniam na casa de Bernardo Rucellai, seja por meio do contato com manuscritos traduzidos para o latim que circulavam na Itália desde a primeira metade do quatroccento. ${ }^{5}$ Maquiavel fez uso de técnicas literárias típicas do gênero trágico. Giorgio Squarotti (1966) defendeu a existência de uma "estrutura trágica" em O Príncipe, baseada em uma con130 cepção da existência política marcada pelo agon heroico. Para Ronald Martinez (2000), Maquiavel estaria bem familiarizado com a discussão literária de seu tempo em razão de sua formação humanista, por ser um autor teatral e por ter participado, pelo menos desde 1515, dos famosos encontros com intelectuais e artistas nos jardins da vila de Rucellai, os Orti Oricellari, em Florença. Nestes encontros, ele teria mantido contato com autores e tradutores de peças trágicas tais como: Luigi Alamanni, que no seu exílio político traduziu a Antígona, de Sófocles; Giovanni Rucellai, que escreveu sua tragédia Rosmunda, em 1515, baseada em um episódio bárbaro que Maquiavel também incluiria na sua História de

\footnotetext{
4 "É inegável que a longo prazo cada um desses grandes mestres da finalidade foi até agora vencido pelo riso, a razão e a natureza: a breve tragédia sempre passou e retrocedeu afinal à eterna comédia do existir, e as 'ondas de incontáveis risos' - nas palavras de Ésquilo - devem finalmente se abater sobre os maiores desses trágicos também" (Nietzsche, 2005, p. 1).

5 O siciliano Giovanni Aurispa visitou a Grécia, em 1413 em 1421 e levou para a Itália 238 manuscritos gregos, com textos de Sófocles, Eurípides e outros. Aurispa se estabeleceu em Florença quando retornou das viagens (Di Maria, 2005, p. 428).
} 
Florença; Giangiorgio Trissino e Ludovico Martelli, que selecionavam textos de Tito Lívio para a elaboração de suas tragédias. Martinez destaca que Maquiavel fez uso de passagens dessas tragédias nas suas comédias A mandrágora e Clizia, bem como teria utilizado certas técnicas típicas de tragédias em suas comédias (Martinez, 2000, p. 105). Também é muito provável que conhecesse a discussão teórica em torno da tragédia grega. Um dos textos mais comentados neste debate, a Poética, de Aristóteles, já estava disponível em seu meio na tradução latina feita por Giorgio Valla desde $1498 .{ }^{6}$

Maquiavel também teve acesso a elementos da visão trágica de mundo nas obras de outros escritores antigos que ele admirava. Nestes textos, ele encontrou ideias trágicas tanto em versões religiosas, tal como apresentadas na mitologia e textos literários dos gregos e romanos antigos, quanto em versões naturalistas, presentes nas obras de alguns filósofos antigos, especialmente os atomistas. A fonte mais antiga da visão trágica encontra-se na religião antiga e na poesia de Homero e de Hesíodo. ${ }^{7}$ Para a religiosidade "pagã" greco-romana, o cosmos surgiu naturalmente, não a partir de uma Criação com um plano, e os deuses habitavam o mesmo mundo que os mortais e não um mundo transcendente. ${ }^{8}$ A religião "pagã" não era uma religião transcendente, mas uma religião do mundo, da natureza (Corrington, 1997, p. 10; York, 2003). A ausência da ideia de Criação, de transcendência e de um plano moral conduzindo os eventos é perceptível, por exemplo, na narrativa grega das três Moiras cegas, que teciam o destino dos homens e dos deuses. $\mathrm{O}$

6 Havia uma boa tradução da Poética de Aristóteles para o latim feita por William of Moerbeke em 1278, mas ela era virtualmente ignorada (Javitch, 1999, p. 54).

7 Para Platão, "Homero é o melhor poeta e o primeiro entre os trágicos" ( $A$ República, 607a). A caracterização de Platão indica que neste trecho ele se refere ao trágico como visão de mundo e não como gênero artístico, afinal Homero era um poeta épico, anterior ao teatro trágico de Ésquilo, Sófocles e Eurípides.

8 "Comparados com o Deus da narrativa bíblica da Criação, os deuses de Homero não eram sobrenaturais, mas parte da natureza [...]. Os deuses de Homero estão no mundo; a natureza é cheia de seres divinos que merecem adoração" (Kaufmann, 1968, p. 152). A partir deste momento todos os textos em língua estrangeira terão tradução nossa. 
que implica que os destinos eram costurados ao acaso, de modo cego, sem necessariamente premiar o justo ou castigar o injusto. $\mathrm{O}$ acaso era primordial e constitutivo. A Teogonia, de Hesíodo, tem início com o verso "Sim bem primeiro nasceu o Caos" (Hesíodo, 1995, p. 111). Nesta visão trágica, o cosmos é entendido como uma sucessão de ordens precárias a partir do acaso primordial (Caos). Isso quer dizer que os mundos que habitam o cosmos surgem de modo "natural" (não planejado) a partir do acoplamento casual entre forças que constituem ordens mais ou menos duráveis. Portanto, na narrativa de Hesíodo, o cosmos está sempre em devir e sujeito ao acaso (Caos), que vem primeiro e não desaparece depois que se ergue uma ordem do cosmos. ${ }^{9}$ Caos permanece nas profundezas e pode reemergir a qualquer momento.

Os filósofos gregos desenvolveram perspectivas naturalistas ao refletirem sobre a physis sem recorrerem aos deuses. Chamamos de "naturalismo" o pensamento da pura imanência, de um cosmos sem "fora", no qual diversos mundos surgem e desaparecem naturalmente, sem que este devir cósmico seja governado por uma vontade onipotente com um plano moral. Restando saber se esse cosmos natural é completamente determinista ou se inclui a ideia de acaso. No primeiro caso, trata-se do naturalismo que se confunde com o materialismo mainstream, um materialismo incompleto, herdeiro de um modo de pensar monoteísta e teleológico, ${ }^{10}$ afinal, se não há um designer onipotente, por que o cosmos seria perfeito e completamente governado por leis necessárias? No

\footnotetext{
9 O acaso também era tema das tragédias gregas. Por exemplo, quando Jocasta tenta consolar Édipo: "Jocasta: O medo em tempo algum é proveitoso ao homem. $\mathrm{O}$ acaso cego é seu senhor inevitável e ele não tem sequer pressentimento claro de coisa alguma; é mais sensato abandonarmo-nos até onde podemos à fortuna instável. Não deve amedrontar-te, então, o pensamento dessa união com tua mãe; muitos mortais em sonhos já subiram ao leito materno. Vive melhor quem não se prende a tais receios" (Sófocles, 1998, p. 68). Note-se que mesmo diante de tal revés da fortuna se recomenda a coragem.

${ }^{10}$ Esse tipo de "naturalismo", segundo Althusser, seria o "materialismo da tradição racionalista", que "é o materialismo da necessidade e da teleologia, quer dizer, uma forma transformada e disfarçada de idealismo” (Althusser, 2006, p. 168).
} 
segundo caso, quando se inclui a ideia de acaso no cosmos natural, estamos falando de um naturalismo trágico.

Muitos comentadores discutiram o naturalismo no pensamento de Maquiavel. ${ }^{11} \mathrm{O}$ naturalismo estaria presente na sua linguagem médica dos humores, corpos mistos e virtù (Gilbert, 1965; Lucchese, 2009), na sua visão do cosmos inspirada no naturalismo da astrologia ptolomaica (Parel, 1992), na sua concepção cíclica de história, inspirada, por exemplo, em Políbio. O historiador grego, pensador da anaciclose, escrevia que "o fato de tudo estar sujeito à decadência e ao desaparecimento é uma verdade a respeito da qual não há necessidade de insistir; a inexorabilidade da natureza basta para convencer-nos disso" (Políbio, 1996, p. 347), enquanto Maquiavel escrevia que "A grande verdade é que todas as coisas do mundo têm seu tempo de vida" (2007b, p. 305). Ambos defendiam ser possível pensar em uma constituição que fosse mais duradoura, mas nenhuma seria eterna, capaz de escapar ao ciclo. Os modernos tendem a ver a concepção cíclica dos antigos como determinista e fatalista. Se Maquiavel fosse partidário dessa teoria, como explicar a sua modernidade? Como explicar o seu apelo à virtù? Qual seria a utilidade do conhecimento sobre a política nesse mundo de necessidade férrea? Apresenta-se, para o comentador moderno, o dilema, desconhecido dos antigos, entre liberdade e necessidade, e a questão de saber que espaço existiria para a liberdade em uma concepção plenamente naturalista.

Para o naturalismo trágico, não há oposição entre contingência e necessidade, o que aparece como necessário pode ser uma acomodação mais estável, mas não eterna, de acasos. Esse naturalismo trágico encontra uma formulação mais acabada entre os filósofos atomistas antigos (Demócrito, Epicuro e Lucrécio) do que em Políbio. O epicurismo foi a fonte antiga mais importante para o que nós chamamos de naturalismo trágico de Maquiavel. Sabe-se que a recepção de Epicuro e

\footnotetext{
11 Sobre Maquiavel como pensador naturalista ver: Baron, 1943; Cassirer, 1963, p. 100; Chabod, 1965, pp. 213-215; Garin, 1965, p. 185; Gilbert, 1965, p. 330; Koyré, 1991, p. 17; Parel, 1992, p. 28; Strauss, 1958, p. 222.
} 
Lucrécio na Renascença italiana foi intensa e teve um impacto importante na formação do pensamento moderno. ${ }^{12} \mathrm{O}$ livro De rerum natura, de Lucrécio, foi levado à Florença por Poggio Braciolini em 1417 e despertou grande interesse no meio intelectual florentino, recebendo inúmeras cópias manuscritas e algumas edições impressas (Brown, 2010a, p. 1; Palmer, 2014, p. xii). A proibição do uso do livro de Lucrécio nas escolas de Florença sinaliza o grau de disseminação da obra. Os cursos oferecidos por intelectuais sobre as filosofias de Epicuro e Lucrécio encontraram grande audiência. Entre estes intelectuais divulgadores do epicurismo em Florença, destacavam-se Bartolomeu Scala e Marcello Adriani. Ambos eram amigos do pai de Maquiavel (Brown, 2010b, p. 69). Outro documento importante da filosofia epicurista disponível no contexto de Maquiavel era A vida de Epicuro, capítulo das Vidas e doutrinas de filósofos ilustres, de Diógenes Laercio. Para Brown (2010a, p. 2), "juntos, estes livros deflagraram o 'naturalismo radical' e uma 'nova visão de mundo' que tradicionalmente marcou a Renascença”.

Hoje sabemos que Maquiavel não apenas leu De rerum natura, mas também copiou o livro inteiro com seu próprio punho, ${ }^{13}$ escrevendo ainda diversas anotações na sua cópia do livro, que está disponível no Vaticano. ${ }^{14}$ Também é provável que tenha lido A vida de Epicuro, de Diogenes Laércio (Rahe, 2007, p. 42). O jovem Maquiavel conviveu com Bartolomeu Scala e Marcello Adriani nos anos 1490, e há indícios de que teria assistido à primeira conferência de Adriani, intitulada "Nihil Admirari", oferecida em 1497, ano em que fez sua cópia do livro de Lucrécio. Seis anos após a morte de Maquiavel, Francesco Guicciardini descreveu o seu amigo como "um cético profundo, inclinado a levantar

\footnotetext{
12 Ver: Greenbalt, 2011; Norbrook; Harrison; Hardie, 2016; Palmer, 2014; Prigogine, 1996.

13 Não queremos sugerir que Maquiavel fosse um seguidor dogmático de Lucrécio, mas apenas constatar que este foi uma das suas principais influências. Sobre Maquiavel e Lucrécio ver: Najemy, 1993, p. 58, 190, 239, 337-338, 342, 346; Viroli, 1998, p. 16; Rahe, 2007; Brown, 2010a, 2010b; 2016; Palmer, 2014.

14 Ver: Bertelli, 1961, p. 10-20; Brown, 2010a, p. 68, 113-122; Finch, 1960, p. 29-32; Merrill, 1926, p. 347; Palmer, 2012, p. 412; Rahe, 2007.
} 
objeções poderosas contra a doutrina cristã segundo a lógica última, senão o próprio argumento de De rerum natura" (Guicciardini apud Rahe, 2007, p. 44). Em 1576, Gentillet observou que Maquiavel

julgava que o curso do sol, da lua e das estrelas; as distinções entre as estações da primavera, verão, outono e inverno; o governo político dos homens; os produtos da terra, frutas, plantas e animais - que tudo isso vem ao mundo por acidente e acaso [à l'aventure et par rencontre], porque ele seguia a "doutrina de Epicuro" [...] que julgava que todas as coisas surgem e acontecem por circunstâncias fortuitas e um encontro acidental de átomos [par cas fortuit et rencontre des atomes]. (Gentillet apud Rahe, 2007, p. 48)

A filosofia epicurista, tal como exposta no livro de Lucrécio, oferece uma visão trágica do cosmos em versão naturalista. Rosset (1989, p. 159) chega a dizer que "Aos olhos do pensamento trágico, Lucrécio aparece assim como o filósofo por excelência”. Seguindo o epicurismo, Lucrécio afirma que tudo que existe no universo é formado por átomos e vazio (Lucretius, 1982, p. 35) e o cosmos não é guiado por nenhum propósito ou intenção. ${ }^{15}$ Demócrito pensava que os átomos se moviam em todas as direções, se chocavam e criavam corpos, sempre segundo leis naturais necessárias ( $\dot{\alpha} v \dot{\alpha} \gamma \kappa \eta$ / necessidade). Epicuro, por sua vez, entendia que os átomos cairiam eternamente em linha reta e na mesma velocidade, devido ao seu peso e à falta de resistência (vazio). Contudo, se assim fosse não teria havido nenhum encontro ou colisão de átomos e nenhum corpo ou mundo teria surgido. Seria preciso, afirma Lucrécio, que os átomos "se inclinassem um

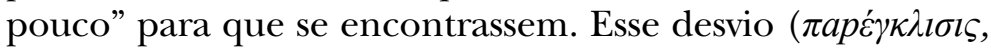
clinamen) não teria como ser previsto ou explicado, e, no

15 "O mundo foi feito pela natureza, e os átomos, chocando-se ao acaso, combinaram-se das mais variadas formas, sem propósito, sem intenção, até que essas combinações, de repente unidas, puderam se tornar em cada caso a origem de coisas grandiosas, da terra, do mar e do céu e das criaturas vivas" (Lucretius, 1982, p. 177). 
entanto, estaria na origem dos encontros fortuitos entre átomos que formam os corpos. O clinamen permite o encontro entre átomos que formam tudo o que existe. Isso significa colocar o acaso ${ }^{16}$ como originário e conduz à imagem de um universo que, por um lado, não muda, pois a soma total de matéria não muda (Lucretius, 1982, p. 119), mas, por outro lado, está em permanente mudança, pois não cessam as combinações entre os átomos, que com seus encontros fazem e desfazem mundos no interior deste universo que não tem um "fora" ${ }^{17} \mathrm{O}$ clinamen também está na origem da liberdade, que não existiria se tudo fosse governado por leis necessárias que remontassem a uma unidade causal (Lucretius, 1982, p. 113116). Neste naturalismo epicurista, graças à contingência ( $c l i$ namen), a liberdade existe, mas não se confunde com a ideia de agência soberana presente nas teorias cristãs e humanistas de livre-arbítrio. A liberdade, para o epicurismo, não é exclusiva do homem, sendo compartilhada também por outros animais (Lucretius, 1982, p. 115). ${ }^{18}$

\section{A visão trágica de mundo de Maquiavel}

\section{Incipit Tragoedia: eternidade e Variazione}

Os heróis trágicos de Maquiavel vivem e agem em um Caosmos que está em eterno devir. Neste universo, "todas as coisas do mundo estão em movimento e não podem ficar paradas, é preciso que estejam subindo ou descendo"

\footnotetext{
16 "Pois tudo o que foi feito pode ser chamado de acidente" (Lucretius, 1982, p. 41). 17 "O universo está sempre em movimento incessante em todas as suas partes, e os elementos da matéria são fornecidos de baixo, correndo no espaço infinito [...] o universo, entretanto, não tem nada fora para ser seu limite" (Lucretius, 1982, p. 83).

18 Pode-se objetar que a ética epicurista da busca pela ataraxia (ausência de ansiedade, paz de alma) não era trágica, e, portanto, Lucrécio não seria uma fonte para o pensamento trágico de Maquiavel. Entretanto, não defendemos aqui que Maquiavel seguisse a ética epicurista, mas apenas a ideia epicurista de natureza. Ver Palmer, 2012, p. 412 e Rahe, 2007, p. 52. Para Rosset (1989, p. 142), o próprio Lucrécio conservou apenas a Física de Epicuro, não sua moral.
} 
(Maquiavel, 2007b, p. 32).${ }^{19}$ Consequentemente, "a grande verdade é que todas as coisas do mundo têm seu tempo de vida" (Maquiavel, 2007b, p. 305). O mesmo ocorre entre os homens, pois "as coisas humanas ora sobem, ora descem" (Maquiavel, 2007b, p. 178), já os corpos mistos (por exemplo repúblicas) podem ter duração maior ou menor, conforme sua capacidade de se renovar e "voltar aos princípios" (Maquiavel, 2007b, p. 305), entretanto, "não existe república perpétua” (Maquiavel, 2007b, p. 378). Roma, a república perfeita (Maquiavel, 2007b, p. 19), morreu. Sempre foi assim e sempre será, "que o mal suceda ao bem e o bem ao mal" ${ }^{20}$. Assim como em De rerum natura, todos os corpos têm um ciclo natural de nascimento, corrupção e morte. A ideia é retomada em História de Florença, quando Maquiavel escreve que "não está na natureza das coisas do mundo o deter-se" e

quando chegam à máxima perfeição, não podendo mais se elevar, convém que precipitem e de igual maneira, uma vez caídas e pelas desordens chegadas à máxima baixeza, necessariamente não podendo mais cair convém que se elevem: assim, sempre do bem se cai no mal e do mal eleva-se ao bem. Porque a virtude gera tranquilidade, a tranquilidade, ócio, o ócio, desordem, a desordem, ruína; e igualmente, da ruína nasce a ordem, da ordem a virtude, e desta, a glória e a prosperidade. (Maquiavel, 1998, p. 229)

19 Rahe considerou que Maquiavel teria sido um discípulo de Heráclito (que era trágico), porque "os seus ensinamentos sobre a política baseiam-se na alegação de que "todas as coisas humanas estão em movimento e não podem permanecer fixas'” (Rahe, 1995, p. 452). Em trabalho posterior, Rahe chegou à conclusão de que Lucrécio foi a fonte direta para que Maquiavel chegasse a essa visão "heraclitiana" do cosmos em perpétuo devir (Rahe, 2007).

${ }^{20}$ Maquiavel, "L'Asino", 5, 103-5: "É, e sempre foi, e sempre será que o mal suceda ao bem, e o bem ao mal, e que um sempre é a causa do outro" (Machiavelli, 1971, p. 967). Em A Mandrágora, Calímaco exclama: "Em que angústia d'alma estive e estou! E é verdade que o fado e a natureza mantêm sempre em equilíbrio as contas do balanço: nunca nos fazem um bem que, de encontro não surja um mal" (Maquiavel, 2004, p. 119). Essa ideia de ciclo natural também aparece em Lucretius (1982, p. 119). 
Consequentemente, não é possível evitar definitivamente a decadência, o que contraria as expectativas (antitrágicas) que se desenvolveram nas perspectivas do "platonismo" e do judaísmo-cristianismo e que foram transmitidas aos seus herdeiros modernos e seculares, em suas expectativas de controle sobre a natureza, "progresso" e harmonia final, presentes nas grandes narrativas que preveem o retorno a uma situação edênica no fim da história. ${ }^{21}$

\section{A Fortuna quer ser árbitra de todas as coisas humanas ${ }^{22}$}

No tempo trágico (cíclico) e sem fim de Maquiavel, os heróis ou superam as dificuldades previstas e imprevistas ou sucumbem, sem nenhuma garantia de justiça final. As dificuldades imprevistas podem ocorrer ao acaso. $\mathrm{O}$ termo preferido de Maquiavel para se referir ao acaso é "Fortuna", nome romano para a deusa que os trágicos gregos chamavam Tyché. O papel importante que ele atribui à 138 Fortuna no curso dos eventos é uma das principais indicações para o considerarmos como um pensador trágico. $\mathrm{O}$ papel da Fortuna e sua relação com a virtù é um dos temas mais comentados no pensamento de Maquiavel. De modo geral, os comentadores que entendem Maquiavel como um

21 Ver Steiner, 2006, p. 184. Para Viroli: "O fluxo das desventuras humanas segue, para Nicolau, um ciclo inexorável. Não existe um progresso em direção à felicidade, ou à salvação, e sim uma eterna sucessão entre a ordem e a desordem, entre a virtude e o vício, entre o bem e o mal. Nada permanece o mesmo, nada se conserva imutável sob o sol: 'e é, e sempre foi, e assim será / que o mal suceda o bem, e o bem o mal', e um será sempre a causa do outro. Isso vale tanto para os Estados e os povos quanto para os indivíduos" (Viroli, 2002, p. 211). Para Araújo (2013, p. 108), a resposta de Maquiavel "ao problema da finitude da república não é a esperança de quebrar a fatalidade do ciclo, mas o uso excelente da temporalidade por parte dos homens [...] até cumprir o seu ciclo, uma república, se for virtuosa, terá impresso no mundo a sua marca, que é a grandeza e a imortalidade de seus feitos". Segundo Araújo (2013, p. 115), "há que reconhecer algo de profundamente 'trágico' nesse realismo", o que "faz seu pensamento desviar-se também de outras tendências modernas, talvez mesmo de seu mainstream".

22 Em Vida de Castruccio Castracani, Maquiavel escreve "a Fortuna quer ser árbitra de todas as coisas humanas" ("Ma la fortuna, che vuole essere arbitra di tutte le cose umane") (Maquiavelli, 1971, p. 625). 
pensador moderno procuram aproximá-lo da ideia moderna do sujeito soberano - do homem como senhor do seu destino -, que se desenvolve no humanismo renascentista. ${ }^{23}$ Nesta visão moderna, com o conhecimento e virtù adequados, o homem teria o poder de vencer, de modo seguro, os caprichos da Fortuna. O texto preferido para os defensores desta tese se encontra no capítulo XXV de O Príncipe, em que afirma: "julgo ser verdadeiro que a fortuna seja árbitra de metade das nossas ações, mas que ela ainda nos deixa governar a outra metade, ou quase" (Maquiavel, 2007a, p. 235). Para os defensores do Maquiavel moderno, essa passagem seria emblemática da crença de Maquiavel na capacidade humana de dominar a Fortuna. Um dos comentadores mais extremos dessa linha de interpretação foi Charles Tarlton, que chegou a defender que para Maquiavel a fortuna poderia ser "completamente superada" (Tarlton, 1968, p. 342). A superação da Fortuna, sua própria existência, dependeria exclusivamente de certas qualidades humanas estarem presentes ou não, tais como a virtù e a prudência. Neal Wood (1972, p. 46) também entendia que a fortuna seria dependente das qualidades humanas e apareceria somente quando a virtù estivesse ausente, declinando a sua influência na presença da virtù. Entretanto, quase nenhum comentador da tendência que acentua a modernidade de Maquiavel adotou uma interpretação tão extrema quanto a de Tarlton. Flanagan (1972, p. 143), por exemplo, também entendia que para Maquiavel a "Fortuna é imanente às atividades humanas", no sentido de que o homem "pode transcender a Fortuna por meio da recusa a jogar o seu jogo", mas isso não significava que a fortuna poderia ser completamente dominada, pois, para Maquiavel,

\footnotetext{
23 Sobre as interpretações de Maquiavel como pensador moderno ver: Kahn, 1985; Pitkin, 1984; Tarlton, 1968. Para os críticos desta visão de um Maquiavel inequivocamente moderno ver: Parel, 1992; Skinner, 1988; 1996; Viroli, 1998.
} 
nós vivemos em um mundo imprevisível, e nossas ações frequentemente não resultam como planejamos [...] o homem nunca se livrará completamente do poder da fortuna; até mesmo planos bem feitos e brilhantemente executados podem falhar em razão de contingências imprevistas. (Flanagan, 1972, pp. 140-141)

Para Balaban (1990), existem ambiguidades nos textos de Maquiavel que forneceriam argumentos tanto para a tese de que a Fortuna pode ser governada quanto para a tese contrária. A questão principal não seria saber se a Fortuna é governável ou não, mas se ela é um subproduto da ação humana ou se seria independente dela. Balaban tentou mostrar que o uso que Maquiavel faz do termo Fortuna só poderia ser compreendido tendo como referência as atividades humanas, em vez dos fenômenos naturais. $\mathrm{O}$ autor propõe um modelo interpretativo baseado apenas nas ações teleológicas, que 140 são conscientes, voluntárias e dirigidas a um objetivo: "Toda ação teleológica visa (1) um objetivo, (2) um objeto no qual esse objetivo é realizado. Toda ação teleológica tem dois tipos de resultados: (a) os que eram desejados pelo agente e (b) as consequências não esperadas pelo agente" (Balaban, 1990, p. 30). Ele se refere aos primeiros (a) como "objetivos" e aos segundos (b), como "subprodutos". Os subprodutos da ação podem ser favoráveis, desfavoráveis ou indiferentes para o agente, e o que Maquiavel chama de Fortuna refiria-se apenas aos subprodutos desfavoráveis da ação humana. Balaban revela em seu texto todo o otimismo moderno que está pressuposto em sua interpretação, chegando a afirmar que

os assuntos humanos não estão sujeitos a eventos naturais. São os eventos naturais que na sua significância, escopo e capacidade limitadora são parte dos assuntos humanos. Isso quer dizer que a natureza é um objeto da ação humana um aspecto da atividade teleológica. Ela é usada pelo sujeito 
de modo a favorecer os objetivos que ele quer realizar. Fortuna torna-se um dado manipulável, o próprio material da ação humana. (1990, p. 33)

Balaban (1990, p. 34) insere assim Maquiavel na sua própria perspectiva humanista moderna, que chega ao auge quando escreve que "Os subprodutos são externos à nossa vontade apenas enquanto nós permanecemos inconscientes de sua existência”. Basta haver consciência e não haverá mais má Fortuna. Os resultados não desejados da ação tornam-se objetos de novas ações, que, por sua vez, resolvem tudo aplicando o conhecimento correto, "assim, a virtude pertence ao domínio dos meios, ou ao domínio do conhecimento técnico dos assuntos humanos" (Balaban, 1990, p. 35).

Concordamos com Balaban que parte do que se designa como Fortuna decorre dos efeitos não esperados das ações humanas, mas não vemos motivo para descartar, como ele arbitrariamente faz, que Maquiavel também considerasse a existência da Fortuna decorrente da natureza, pois essa dimensão também aparece em inúmeros de seus textos, incluindo os literários. Os limites à virtù não decorrem apenas do campo dos resultados não esperados das ações humanas. Por exemplo, Martinez mostrou que a conclusão da peça Clizia

ratifica a visão de Maquiavel de que a Natureza impõe limites absolutos à flexibilidade da virtù: mesmo aqueles que dominam a Fortuna eventualmente cairão ante o limite absoluto da Natureza, que decreta a senescência de todos os corpos mistos, de indivíduos às cidades-estado e repúblicas. (1993, p. 136)

Maquiavel seria um seguidor da "sabedoria délfica", por sua visão dos "limites da autonomia heroica" e do "encontro fatal da virtù com o declínio e a morte" (Martinez, 1993, p. 138). É de se ressaltar que a "sabedoria délfica" perpassava a literatura trágica antiga. Martinez remete aos trechos dos Discursos 
(Livro 1, cap. 2; Livro III, caps. 1 e 9) em que Maquiavel escreve sobre nascimento e renascimento, doença e envelhecimento, para descrever a ascensão e queda dos estados.

Quentin Skinner não concorda com os comentadores que atribuem a Maquiavel a crença em um domínio completo da virtù sobre a Fortuna. Para ele, nem os próprios humanistas teriam tanta fé, pois apesar de terem desenvolvido a crença na capacidade humana de alcançar a virtù e "esculpir o seu destino", também recuperaram a ideia antiga de que o limite a esta pretensão não é nenhuma Providência divina, mas o "poder caprichoso da Fortuna" (Skinner, 1996, p. 117). Skinner (1996, p. 117) afirma que a ideia de um poder caprichoso da Fortuna levou alguns humanistas a um "extremo pessimismo", e cita como exemplo a obra de Poggio, ${ }^{24}$ A miséria da condição humana, que "lamentava a licença e poder da Fortuna sobre as coisas humanas”. O texto mais próximo da fé moderna no domínio sobre a 142 Fortuna teria sido O Príncipe (1513), entretanto, segundo Skinner (1996, p. 207), há uma gradativa redução desta esperança nas obras seguintes, Discursos sobre a primeira década de Tito Livio (1519) e História de Florença (1525). Para o autor, esse declínio da fé no poder da virtù sobre a Fortuna estava presente no contexto de Maquiavel, e com este declínio "a grande tradição do republicanismo italiano foi chegando ao fim" (Skinner, 1996, p. 207). Maquiavel teria sido sobretudo um crítico do humanismo e sua concepção de história era "fatalista, em última análise" (Skinner, 1996, p. 207). ${ }^{25}$

\footnotetext{
${ }^{24}$ A afirmação de Skinner sobre Poggio ganha especial interesse para nós, pois sabemos que Poggio introduziu Lucrécio em Florença e entendemos que a obra deste epicurista apresenta uma visão trágica do cosmos.

25 Para Viroli (1998, pp. 17-18), "contrariamente à opinião de alguns estudiosos, Maquiavel não se declarou de nenhuma forma em favor do progresso em termos que nós possamos reconhecer; nem compartilha as crenças modernas a respeito da liberdade perfeita e a capacidade de os homens obterem controle sobre si mesmos e sobre o mundo. Sua visão da evolução humana é cíclica, não progressista".
} 
Ernst Cassirer (1946) também havia sido enfático em desvincular Maquiavel das ideias modernas de domínio total sobre a fortuna a partir de um conhecimento científico determinista. Para Cassirer, Maquiavel pensava que

mesmo o melhor conselho político é frequentemente inefetivo. As coisas irão por seu próprio caminho; frustrarão todos os nossos desejos e propósitos. Mesmo os esquemas mais astutos e habilidosos são falíveis. Essa incerteza nos assuntos humanos parece tornar toda ciência política impossível. Aqui nós estamos vivendo em um mundo inconstante, irregular e caprichoso que desafia todos os nossos esforços de cálculo e previsão [...]. A Fortuna parece governar as coisas. (Cassirer, 1946, p. 157)

O tema aparece nas cartas trocadas entre Maquiavel e seu amigo Francesco Vettori entre 1513 e 1515. As cartas foram analisadas cuidadosamente por John Najemy, que considerou, como tema central das cartas, a inteligibilidade dos fenômenos políticos que apresentavam grande variação (variazione) e a capacidade do discurso teórico para controlar "os caprichosos e imprevisíveis eventos" (Najemy, 1993, p. 177). Vettori defendia uma posição fortemente cética a este respeito. Maquiavel, naquele momento, demonstrava resistir ao ceticismo, argumentando em defesa da possibilidade de um conhecimento sobre a política que fosse além da imaginação (immaginazione) e pudesse alcançar a "verdade efetiva das coisas" (verità effetuale della cose) e, com isso, controlar a Fortuna. Portanto, neste debate entre Maquiavel e Vettori estão em jogo alguns pontos centrais daquilo que chamamos no início deste artigo de "visão trágica de mundo", pontos que giram em torno do papel da contingência, dos limites do conhecimento e da limitada capacidade humana de controlar o destino.

Em carta a Maquiavel, Vettori escreve que "as coisas não ocorrem com base na razão" e que "seria supérfluo falar, 
discursar ou argumentar sobre elas" (Machiavelli, 1971, p. 1143). Para Najemy (1993, p. 176), Maquiavel queria responder ao desafio posto pelo ceticismo do amigo, por isso "o imediato interlocutor de O Príncipe era o próprio Vettori”. O livro representaria o auge da longa argumentação de Maquiavel com Vettori e esta polêmica "culmina nos capítulos 25 e 26 de O Príncipe” (Najemy, 1993, p. 201). Segundo Najemy, quando Maquiavel escreve, no capítulo 25, que "muitos tiveram a opinião que as coisas do mundo são governadas pela Fortuna", não haveria dúvida que entre estes "muitos" Maquiavel incluía Vettori. Também não haveria dúvida que o comentário de que muitos "chegaram a esta conclusão" em razão das "grandes mudanças nas situações" (variazione) ecoa a afirmação de Vettori de que "as coisas não acontecem com base na razão". Para Najemy, quando Maquiavel afirma "eu algumas vezes, inclinei-me de certo modo pela opinião deles", estaria se referindo a uma carta que escreveu a Vettori no dia 1449 de abril de 1513. Apesar de certa inflexão "moderna" de Maquiavel em O Príncipe, Najemy considera que Maquiavel acaba endossando as posições céticas de Vettori nos textos posteriores a $O$ Príncipe $^{26}$ e que mesmo neste livro, no capítulo $\mathrm{XXV}$, Maquiavel não estaria completamente seguro de sua posição. A insegurança transparece quando ele escreve que o nosso livre arbítrio governa "a metade ou quase" e que ele mesmo se inclinou "algumas vezes" à opinião contrária que dizia que as coisas eram governadas pela Fortuna. Mais que simples insegurança, segundo Najemy (1993, p. 205), ocorre até mesmo um ponto de virada no próprio capítulo XXV em direção a uma posição cética mais próxima a Vettori. Nesta virada, Maquiavel reaproxima-se também de posições que ele próprio defendeu em outros textos, nos quais expressa a sua teoria do encontro (riscontro). Najemy (1993, p. 205) chega a

\footnotetext{
${ }^{26}$ Najemy (1993) e Skinner (1988; 1996) e Di Maria (1992, p. 258, 263) concordam que o peso da Fortuna e o ceticismo a respeito da nossa capacidade de conhecê-la e controlá-la aumentam nos textos posteriores a $O$ Príncipe.
} 
dizer que Maquiavel "repete de modo idêntico" o que havia escrito na Ghiribizi. Portanto, no centro do capítulo em que culmina a polêmica com Vettori, Maquiavel acaba cedendo na sua tentativa de argumentar que seria possível controlar a Fortuna de modo seguro a partir de um conhecimento preciso sobre a política.

Althusser (2006) também destacou o tema da contingência e a afinidade de Maquiavel com materialismo de Lucrécio $^{27}$. Ele ofereceu cursos sobre Maquiavel e suas anotações deste período deram origem ao livro Machiavel et nous, escrito provavelmente em 1968 (Althusser, 1999, p. vii). A reflexão é aprofundada nos textos sobre o "materialismo do encontro", escritos entre 1977 e 1987. Para Althusser, no núcleo do pensamento político de Maquiavel está a ideia de que "um encontro precisa acontecer": o encontro feliz entre a virtù e a Fortuna. Encontrando a Fortuna, o príncipe precisa ter a virtù para conquistá-la e "fazer o seu destino", entretanto, "o encontro pode acontecer e pode não acontecer. $\mathrm{O}$ encontro pode se perder. $\mathrm{O}$ encontro pode ser breve ou duradouro. Ele precisa de um encontro que dure" (Althusser, 2006, p. 172). ${ }^{28}$

\footnotetext{
27 Althusser (2006, p. 167, 169, 190-192) entendia que a origem do "materialismo do encontro" estava no epicurismo e em Lucrécio e defendeu que Maquiavel era um dos pensadores dessa corrente.

28 Lefort frequentou os cursos de Althusser e também destacou a teoria do encontro no pensamento de Maquiavel: "Um dado período exige um certo tipo de caráter e estilo de ação; entretanto, nós esquecemos as condições particulares e buscamos no último, em um princípio pessoal, a explicação do sucesso na política. Mas deixe as condições mudarem e nós seremos forçados a admitir que aquilo que parecia conduzir à grandeza agora é causa de sua ruína. É por isso que a ideia de Fortuna é tão vividamente sentida por nós. Felicidade e infelicidade não são exclusivamente de nossa responsabilidade; elas são fruto de um encontro. Embora ainda esteja ao nosso dispor agarrar a ocasião, a ocasião é um presente; e desse presente não há nada a ser dito, nem nada para ser conhecido sobre sua origem” (Lefort, 2012, p. 197).
} 


\section{Teoria do encontro e agência não soberana}

A teoria do encontro aparece de modo explícito nos textos literários de Maquiavel, ${ }^{29}$ em cartas ("Ghiribizzi", 1506), em O Príncipe (1513), nos Discursos (1519) e em A Vida de Castruccio Castracani (1520), portanto está presente em todas as fases de sua obra. Esta teoria é eminentemente trágica, pelo grau de poder atribuído à Fortuna, pela visão da limitação da capacidade humana para dominá-la. Também é trágica a postura afirmativa de Maquiavel frente a essa realidade, com seu apelo à coragem e virtù para que, mesmo nestas condições, tentemos realizar grandes ações no mundo (afirmação trágica), e, caso não seja possível, saibamos cair com dignidade. Há um agon trágico entre virtù e Fortuna que concede grandeza aos personagens e seus feitos. ${ }^{30}$ Estas duas dimensões - descrição do real tal como aparece na teoria do encontro e a postura afirmativa recomendada diante deste real - constituem o núcleo da 146 "visão trágica do mundo" a que nos referimos no início deste artigo.

A famosa carta "Ghiribizzi" e o poema "Di Fortuna" foram escritos no mesmo período e constituem as primeiras manifestações da "teoria do encontro" de Maquiavel. Estes textos, e as cartas trocadas com Vettori entre 1513 e 1515 , constituem um material riquíssimo para a compreensão da visão de mundo de Maquiavel e, consequentemente, para uma apreciação adequada de sua teoria política. A carta "Ghiribizzi" e o poema "Di Fortuna" foram escritos em um contexto histórico e pessoal bastante significativo, pois neste ano de 1506 Maquiavel fez parte da delegação

\footnotetext{
29 Especialmente nos poemas "Di Fortuna" e "L'Asino" e na peça A Mandrágora. Sobre a teoria do encontro em A Mandrágora, ver Ferroni (1972, p. 80-87).

${ }^{30} \mathrm{O}$ enfrentamento com o destino e a dignidade da queda eram temas típicos de tragédias e aparecem nas comédias de Maquiavel. Calímaco diz em A Mandrágora: "Arrosta o destino; foge o mal, mas se não podes fugi-lo, suporta-o como homem; não te prosternes” (Maquiavel, 2004, p. 120).
} 
florentina que acompanhou o Papa Júlio II em sua reconquista da parte central da Itália. Maquiavel ficou impressionado com o que presenciou e, mais tarde, no capítulo XXV de $O$ Príncipe, retrataria o Papa Júlio II como um líder de virtù e caráter impetuoso. Chama a atenção que esta descrição vem precisamente no parágrafo anterior à sua metáfora da Fortuna como uma mulher que prefere aqueles que são "mais ferozes e comandam-na com mais audácia" (Maquiavel, 2007a, p. 243). Entretanto, diz Maquiavel, se a audácia do Papa Júlio II lhe foi favorável naquele contexto, "se sobreviessem tempos nos quais fosse necessário proceder com prudência, daí seria sua ruína: porque nunca se teria desviado daqueles costumes, aos quais a natureza o inclinava" (2007a, p. 241). Ou seja, mesmo alguém audacioso e com virtù estaria sujeito à ruína, porque não seria capaz de alterar seu modo de proceder de acordo com a necessidade dos tempos, limitado que estava por aquilo a que a sua natureza o inclinava. Esta teoria já estava exposta de maneira explícita na "Ghiribizzi”, quando afirma que "é feliz quem encontra [riscontra] o seu modo de proceder com o tempo, e, ao contrário, é infeliz aquele que diverge, com suas ações, do tempo e da ordem das coisas" (Maquiavel, 2015, p. 273). Na carta, Maquiavel levanta a possibilidade de surgir alguém que "fosse tão sábio que conhecesse os tempos e as ordens das coisas e se acomodasse a elas", e, fazendo isso, "teria sempre boa fortuna”. Entretanto, prossegue Maquiavel, "destes sábios não se encontra, tendo os homens antes a vista curta, e não podendo comandar sua natureza, segue-se que a Fortuna varia e comanda os homens e os têm sob seu jugo" (Maquiavel, 2015, p. 275). Quer dizer, seria possível imaginar um homem que, em posse do conhecimento adequado e com uma flexibilidade sem limite, dominasse a Fortuna, mas este seria quase um além-homem, alguém que teria que renunciar às suas características humanas, ao seu temperamento, hábitos, vínculos religiosos e pressupostos 
morais arraigados para fazer aquilo que fosse necessário, de acordo com os cambiantes tempos, para se preservar e alcançar a grandeza.

No poema "Di Fortuna", Maquiavel (2011, p. 241) menciona que seria bom poder "saltar de roda em roda", e quem o fizesse seria sempre feliz, mas este poder nos é negado "pela oculta virtù que nos governa" e o indivíduo não pode "mudar de pessoa":

Porque, enquanto tu és girado pelas costas, pela roda, agora feliz e boa, ela costuma mudar os giros no meio do curso; e, não podendo tu mudar de pessoa nem abandonar a ordem da qual o céu te dota, no meio do caminho ela te abandona. Porém, se isto se compreende e nota, seria sempre feliz e beato, quem pudesse saltar de roda em roda. Mas, porque este poder nos é negado pela oculta virtù que nos governa, muda, com seu curso, o nosso estado. Neste mundo, nenhuma coisa é eterna: a fortuna o quer assim, disso ela se embeleza, a fim de que seu poder mais se distinga.

(Maquiavel, 2011, p. 241)

A teoria trágica do encontro também está presente nos textos políticos mais famosos de Maquiavel. Nos Discursos: "Já considerei várias vezes que a razão da má e da boa fortuna dos homens vem do ajuste de seu modo de proceder com os tempos" (Maquiavel, 2007b, p. 351). No capítulo 25 de $O$ Príncipe, o supostamente mais moderno do livro mais moderno de Maquiavel, esta teoria trágica aparece quando ele explica que o sucesso das ações depende de um encontro (riscontro) do "modo de proceder com os atributos do 
tempo". ${ }^{31} \mathrm{O}$ "encontro" não é fácil, pois os tempos variam muito (variazione), o que exige diferentes modos de proceder dos agentes políticos. Entretanto, "nem se encontra homem assim tão prudente que saiba se acomodar a isto", porque por mais "prudência" ou conhecimento da política que uma pessoa tenha, ela "não pode desviar-se de sua inclinação natural” (Maquiavel, 2007a, p. 239). Nos Discursos, esta ideia trágica de um agente que não é soberano - quer dizer, que não "comanda a sua natureza" -, é retomada e associada à durabilidade das formas de governo, pois Maquiavel argumenta que as repúblicas têm vida mais longa que os principados, porque se acomodam à diversidade dos tempos, em razão da diversidade dos cidadãos que nelas há, enquanto o principado duraria menos (Maquiavel, 2007b, p. 352-353). Inclinações naturais e hábitos limitam a flexibilidade dos agentes, o que enfraquece (sem eliminar) sua capacidade de seguir a prudência de modo a fazer o necessário em cada contexto para agarrar a Ocasião, esta deusa fugidia que não tem cabelo nas costas.$^{32}$ Como nas tragédias gregas, em Maquiavel a falta de flexibilidade do agente pode induzi-lo ao erro (hamartia) ${ }^{33}$ que precipita a sua queda. ${ }^{34}$

\footnotetext{
31 "Creio, ainda, que seja feliz aquele que conforma [riscontra] o seu modo de proceder com os atributos do tempo; do mesmo modo creio infeliz aquele cujo proceder diverge do tempo" (Maquiavel, 2007a, p. 237).

32 No poema "Dell'Occasione", de Maquiavel, a Ocasião fala: "Todo cabelo me foi tirado detrás da cabeça, por isso, em vão, alguém se afaina se lhe acontece que eu o tenha ultrapassado ou se me viro" (Maquiavel, 2011, p. 247).

33 Nas tragédias gregas a mudança de fortuna do herói para pior não provém da maldade ou pecado, como punição "bem merecida". A queda do herói é fruto de um erro (hamartia) (Aristóteles, 2005, p. 32), mas entendido em termos prudenciais, não em sentido moral. O erro prudencial é frequentemente indicado ao próprio herói por outros personagens durante a peça, mesmo assim o herói, dominado pelo seu pathos, segue seu comportamento habitual, e, mudando a situação sem que ele próprio mude, o herói "erra", provocando a peripécia que dá início a sua queda.

${ }^{34}$ Como observou Aranovitch (2013, p. 76), "O riscontro, desse modo, deixa de ser apenas o encontro entre a ação humana, compreendida como a ação pontual de um homem, e os tempos, e torna-se o encontro entre a construção de toda estrutura política e as mudanças dos tempos".
} 
A vantagem das repúblicas, porém, vira uma desvantagem no final da seção citada, quando Maquiavel escreve que as ordenações das repúblicas "são mais lentas", aparentemente porque dependem de um número maior de pessoas para tomar decisões, e, para agirem de modo menos lento, precisam de "tempos que comovam toda a república".

A visão trágica acerca da flexibilidade limitada dos homens implica a rejeição da ideia moderna de livre-arbítrio, que nasceu da resposta cristã ao "problema do mal" (visão que seria mais tarde transmitida para o humanismo secular moderno). ${ }^{35}$ Nessa concepção, haveria algum ponto incondicionado e permanente na alma, a "razão", que seria capaz de determinar de modo infalível o corpo, os desejos, humores, afetos e as inclinações naturais. Isso encontrava paralelo na ideia de um Deus transcendente que possuía uma vontade incondicionada. Quando esta ideia entra em crise em certos círculos intelectuais, a pretensão de "sobe150 rania” do sujeito também passa a ser vista como problemática, na medida em que não conta mais com a hipótese de um ponto incondicionado "fora" das múltiplas determinações. Para Maquiavel, não existe "livre-arbítrio" no sentido cristão ou humanista. A liberdade não existe em oposição à "necessidade", como "autonomia" que se expressaria quando a razão prevalece sobre os desejos. ${ }^{36}$ Liberdade para Maquiavel existe na esfera dos desejos, não em oposição a eles, sendo compartilhada também pelos outros animais (como também pensava Lucrécio). Nesta perspectiva natu-

\footnotetext{
35 Ver Connolly (2002).

36 "Quando Machiavel divisa a possibilidade de tomar decisões livres, ele não subtende de nenhuma forma uma instância exterior ao curso da natureza; a vontade é tão condicionada por fatores naturais, os instintos, as tendências naturais contra as quais ninguém pode agir como a queda de uma pedra é determinada por seu peso. [...] O homem é um pedaço da natureza e não pode de nenhuma forma se livrar de suas leis. Ele não é livre senão na medida em que pode agir com base em suas próprias decisões; ser livre não significa ser libertado dos condicionamentos naturais" (Horkheimer, 1974, p. 34 apud Aranovitch, 2013, p. 89).
} 
ralista, não há um corte radical entre o humano e o animal e os animais também têm liberdade e virtude. ${ }^{37}$

O naturalismo de Maquiavel está de acordo com a visão de natureza de Lucrécio e não implica determinismo biológico. Em Lucrécio, a natureza não é determinista, pois possui regularidades mais ou menos duráveis, mas não determinismo, pois existem os desvios dos átomos ao acaso (clinamen). Na cópia de De rerum natura de Maquiavel, ao lado da linha 82 do livro II, sobre movimentos espontâneos dos átomos no vazio, Maquiavel anotou: "uma mente livre". Ao lado das linhas 250-255, em que Lucrécio trata do clinamen, Maquiavel escreveu "do movimento existe variedade, e dela nós temos uma mente livre" (Brown, 2010, p. 74). Dizer que a "vontade livre" 38 existe graças à indeterminação da natureza não pode satisfazer a expectativa forte de controle e "soberania" que existe na ideia moderna (cristã e humanista) de sujeito, pois, ainda que exista maleabilidade, ela seria limitada e não estaria à disposição completa do sujeito. De qualquer forma, não existe aqui um dilema entre naturalismo e liberdade como aparece nas interpretações de muitos comentadores de Maquiavel.

Maquiavel não nega que a educação influencie os comportamentos. Nos Discursos, por exemplo, defendeu que a educação antiga (pagã) formava indivíduos fortes e "amantes da liberdade", enquanto a nossa educação moderna (cristã) estimulou a fraqueza (Maquiavel, 2007b, p. 189-190). Entretanto, para Maquiavel, a educação não

\footnotetext{
37 "Como ocorre com os homens, há cavalos de pouco animo e outros de animo bastante: e muitas vezes um cavalo animoso é montado por um homem covarde, e um cavalo covarde por um homem animoso" (Maquiavel, 2007b, p. 245).

38 "Ao ler Maquiavel através das lentes de Lucrécio, fica claro que liberdade para ele significa vontade livre (free volition) [...]. Isto tem pouco ou nada a ver com a liberdade moral dos cristãos de escolherem entre o bem e o mal [...]. Ademais, ele evidentemente compartilhava a crença de Lucrécio de que essa liberdade mental era um atributo natural de 'todas as criaturas livres', dos homens e dos animais" (Brown, 2016a, p. 73)
} 
se exerce sobre uma tábula rasa, pois inclinações naturais podem oferecer resistência. Um exemplo aparece na biografia de Castruccio Castracani, onde Maquiavel nos diz que Castruccio havia sido criado pelos seus pais adotivos para ser sacerdote, entretanto, desde bem jovem era "de todo diferente do ânimo sacerdotal". Quando chegou aos catorze anos de idade, "pôs de lado os livros eclesiásticos e começou a tratar das armas", e só queria saber de correr, saltar, manejar armas, e nesses exercícios demonstrava "grandíssimo valor de espírito e de corpo", o que provocava no seu padrasto "dor e aborrecimento inestimável" (Maquiavel, 2003, pp. 13-18). Até que o senhor Francesco Guinigi observa os exercícios do jovem Castruccio e o convida para receber treinamento militar. Ele aceita e inicia uma carreira militar de sucesso. Quer dizer, apesar da educação religiosa e da intenção do padrasto, a tendência natural ou espontânea de Castruccio o levava a outro 152 caminho. O destino feliz de Castruccio foi fruto de uma combinação de acasos e de sua virtù para agarrar a oportunidade (Occasione) oferecida por Francesco. Este encontro (riscontro) permitiu que Castruccio alcançasse sucesso e que sua história se tornasse digna de ser contada a todos aqueles que "com ações virtuosas se deleitam" (Maquiavel, 2003, p. 14).

Ainda, como expressão do naturalismo que dilui as fronteiras entre natureza e cultura, temos a passagem dos Discursos em que Maquiavel relacionou as diferenças dos juízos (giudizio) e desejos (appetiti) com diferença de força ou vigor (forze) na juventude e na velhice, quer dizer, as perspectivas diferentes são afetadas pelo ciclo natural do corpo (Maquiavel, 2007b, p. 180). Em carta a Vettori, este tema da influência de tendências "naturais" sobre as perspectivas aparece novamente quando Maquiavel diz a seu amigo que as divergências entre eles na análise política da situação da Lombardia deviam-se aos seus diferentes 
"sentimentos naturais" e "temperamento". ${ }^{39} \mathrm{O}$ mesmo indivíduo pode ser afetado por diferentes educações e costumes, mas não escolheu estas quando nasceu, ele encontrou-se em determinada região, família, classe e, ao longo de sua vida, se encontrará com diferentes estímulos. Isso significa que o indivíduo pode mudar de perspectiva a partir de seus encontros com o mundo e de mudanças no seu corpo (juventude, velhice), mas não necessariamente como eles (conscientemente) gostariam e não sem resistências, pois eles estão no meio de um processo em que são afetados por múltiplas determinações. Maquiavel pensava que haveria espaço para a "vontade livre", na medida em que nem tudo é necessário, que há contingência fornecendo possibilidades de ação, havendo, portanto, espaço para a prudência. Essa maquiaveliana ideia de "vontade livre" contraria certas expectativas modernas de soberania do sujeito, mas é compatível com a ideia trágica de agência não soberana.

\section{Pleonexia}

Além de inclinações naturais e pequena flexibilidade do temperamento, outro obstáculo para certas pretensões políticas modernas é que os homens seriam dominados por apetites e

os apetites humanos são insaciáveis, porque, tendo os homens sido dotados pela natureza do poder e da vontade de desejar todas as coisas e pela fortuna de poder conseguir poucas, o resultado é o contínuo descontentamento nas mentes humanas e o fastio das coisas possuídas: o que leva a

\footnotetext{
39 "Eu suspeito que seu juízo e o meu tenham a mesma base - um sentimento natural ou temperamento que faz você dizer 'não' e eu dizer 'sim'. Você justifica o seu 'não' apontando que se o rei retomasse a Lombardia, haveria mais dificuldade para o estabelecimento da paz; para justificar o meu 'sim', eu apontei que isso não é verdade - ademais, a paz obtida pelo meu método seria mais segura e estável”. (Maquiavel apud Viroli, 1998, p. 70.
} 
condenar os tempos presentes, a louvar os tempos passados e a desejar os tempos futuros, mesmo que a isso não sejam movidos por nenhum motivo razoável. (Maquiavel, 2007b, p. 180)

Sendo os apetites insaciáveis, tão logo os homens alcançam um objetivo já buscam outro e quando não conseguem alcançá-lo frustram-se e condenam os tempos presentes. Quer dizer, condenam por frustração, ressentimento, mesmo sem "nenhum motivo razoável”. Para Maquiavel, o desejo de querer mais, de superar resistências e ir além, impulsiona os homens e, nesta busca, frequentemente entram em conflito e exercem domínio uns sobre os outros. Fazem-no não por maldade, mas porque essa é a sua natureza:

A razão disso é que a natureza criou os homens de tal modo que eles podem desejar tudo, mas não podem obter tudo, e, assim, sendo o desejo sempre maior que o poder de adquirir, surgem o tédio e a pouca satisfação com o que se possui. Daí nasce a variação da fortuna deles. (Maquiavel, 2007b, p. 113)

A insaciabilidade muitas vezes leva ao desejo de conquistar e, para Maquiavel,

é verdadeiramente coisa muito natural e ordinária desejar conquistar: e sempre quando os homens o fazem e podem serão louvados ou não censurados; porém, quando eles não podem, e desejam fazê-lo de todo modo, aqui está o erro e a censura. Portanto, se a França pudesse com as suas forças assaltar Nápoles, deveria fazê-lo. (Maquiavel, 2007a, p. 53)

Maquiavel retoma, portanto, a ideia da pleonexia como característica da natureza humana, tema frequente nos 
textos dos escritores antigos. ${ }^{40}$ Maquiavel se referiu a estes "escritores antigos" nos Discursos e escreveu em seguida "Porque sempre que os homens não precisam combater por necessidade, combatem por ambição; e esta é tão poderosa no peito humano que nunca, seja qual for a posição atingida, o homem a abandona" (Maquiavel, 2007b, p. 113). O foco no desejo e na pleonexia é coerente com seu projeto de entender a política em termos naturalistas, sem visualizar transcendência da esfera natural das inclinações, dos desejos e dos humores. Não há cidade que não viva um conflito entre os humores dos cidadãos. ${ }^{41}$ Se o povo é o guardião da liberdade para Maquiavel, ele o é não por bondade intrínseca, mas porque não está em condição de oprimir. Maquiavel não idealiza a plebe. Os grandes e o povo não estão separados por uma barreira moral, mas por disporem de diferentes graus de poder. Os grandes estão em posição que lhes possibilita exercer o domínio. Sendo assim, o apetite insaciável assume neles a forma de desejo de comandar e oprimir. O povo, em contraste, não está em condição de oprimir ${ }^{42}$ e o apetite insaciável neles assume a forma de "resistência" ao domínio, de não desejar ser comandado nem oprimido. Mas se o povo vence as resistências que se

40 A palavra grega pleonexia é derivada do verbo $\pi \lambda \varepsilon o v \varepsilon \kappa \tau \varepsilon ́ \omega$ (pleonekteó), que significa "o desejo de ter mais", ou, dependendo do contexto, o "prazer em ultrapassar". O substantivo pleonexia derivado do verbo é comumente traduzido como "ambição ilimitada". O termo é frequente nos textos dos antigos e pode ser encontrado nas obras de Tucídides, Xenofonte, Plutarco, Isócrates, Demóstenes, Políbio, Lucrécio, entre outros. Platão também considerava a pleonexia como dominante na maioria dos seres humanos (apenas os filósofos poderiam escapar a ela). Ver Platão (2006, p. 50, 370). Ver também Aristóteles (1985, p. 53).

41 "Porque em toda cidade se encontram estes dois humores diversos: e nasce, disto, que o povo deseja não ser nem comandado nem oprimido pelos grandes e os grandes desejam comandar e oprimir o povo" (Maquiavel, 2007a, p. 105). Ver também Maquiavel (1998, p. 143). O uso do termo humores (umori), típico do vocabulário médico, é coerente com o naturalismo (Gilbert, 1951, pp. 51-55; Lucchese, 2009, p. 75).

42 "Sendo os populares encarregados da guarda da Liberdade, é razoável que tenham mais zelo e que, não podendo eles mesmos apoderar-se dela, não permitirão que outros se apoderem" (Maquiavel, 2007b, p. 24, grifos nossos). 
lhe opõem, passa a querer mais que simplesmente "não querer ser comandado". Movido por pleonexia, buscará comandar também, como a plebe romana, que

não se contentou em obter garantias contra os nobres com a instituição dos tribunos, desejo ao qual foi forçada por necessidade; pois ela, tão logo obteve isso, começou a lutar por ambição e a querer dividir cargos e patrimônios com a nobreza, como coisa mais valiosa para os homens. (Maquiavel, 2007b, p. 113)

Uma vez assegurada a participação no comando, a plebe quererá mais, almejando governar sozinha, como em Florença, onde a plebe quis excluir a nobreza do poder, por isso "o desejo do povo florentino era injurioso e injusto" (Maquiavel, 1998, p. 143). O conflito em Florença não foi positivo para a liberdade como havia sido em Roma e a 156 plebe em Florença caiu por sua própria desmedida (hybris), por sua ambição ilimitada (pleonexia). Nos textos trágicos dos escritores antigos, a pleonexia pode funcionar tanto como um estimulante para a realização de grandes ações, quanto pode ser um inimigo interno que leva o herói à sua própria queda. ${ }^{43}$

Maquiavel não crê que a pleonexia possa ser eliminada, como pretenderam algumas interpretações do cristianismo e, principalmente, alguns dos herdeiros da moral cristã seculares e humanistas. Consequentemente, o conflito também não pode ser eliminado. Maquiavel está sustentando uma posição trágica quando defende que o conflito social não pode ser eliminado, mas pode, em determinadas

\footnotetext{
43 Um dos temas principais das tragédias gregas era a pleonexia do herói provocando sua própria infelicidade. Se não há inimigo "interno" não há tragédia. Este tema também aparece em historiadores "trágicos" lidos por Maquiavel, como Tucídides. Ver: Bedford e Workman (2001, p. 65).
} 
circunstâncias, ser produtivo. ${ }^{44}$ Esta posição trágica acerca do conflito difere do ideal de harmonia sem conflito da filosofia política clássica e do ideal de uma harmonia sem conflito no fim da história, oriundo da tradição judaico-cristã. Em contraste com essas duas fontes poderosas - e antitrágicas - do pensamento político ocidental, Maquiavel pensa que não haverá reconciliação final com ausência de classes sociais e de conflito, nem haverá transcendência da natureza, dos desejos, dos humores e das ambições. Para Maquiavel, nada disso será eliminado, nem por meio da razão nem por um molde social benéfico. Mas esses humores e conflitos podem ser canalizados de forma produtiva. Nesse sentido, Skinner (1988, p. 103) apropriadamente escreveu que para Maquiavel a república deve estar organizada de modo a produzir um "equilíbrio tenso entre forças sociais opostas". ${ }^{45}$ Não se trata, portanto, de eliminar a ambição, mas de torná-la "útil à República”, como observou Mansfield (1996, p. 89). Mesmo a potencialmente perigosa ambição dos grandes pode ser canalizada, para Maquiavel, e, como destacou Silva (2013, p. 53), "sob condições adequadas, os grandes podem constituir-se em uma força positiva. Não se trata de anular por completo seu desejo de dominação, mas de mantê-lo alinhado com a persecução do bem comum e a manutenção da Liberdade”. Para que a ambição dos nobres se mantenha alinhada com estes fins, Maquiavel não recorre

\footnotetext{
44 A valorização da disputa (espírito agonal) era uma característica central da cultura grega na Era trágica (Burckhardt, 2009) e aparece com frequência na obra de Homero. Hesíodo considerava o conflito inerradicável, mas também fez questão de diferenciar entre a má Éris (luta destrutiva) e a Boa Éris (luta produtiva) (Hesíodo, 1996, p. 26). Heráclito fez do conflito o motor das mudanças e foi um pensador da "harmonia conflitual". Ver Heráclito, fragmentos: LXXV, LXXVIII, LXXXI, LXXXII, LXXXIII (Kahn, 1979).

45 "A solução, argumenta Maquiavel, consiste em organizar as leis relativas à constituição de modo a produzir uma relação de equilíbrio tenso entre essas forças sociais opostas, na qual cada uma das partes permanece envolvida com os negócios do governo, e cada uma 'mantém a outra sob vigilância' para impedir tanto 'a arrogância do rico' quanto a 'licenciosidade do povo'” (Skinner, 1988, p. 103).
} 
a nenhuma teoria normativa de tipo deontológico ou categórico. Não há saída "transcendente" nem razão incondicionada que se imponha de fora sobre os humores. Maquiavel entende que o equilíbrio viria do contrapeso de um humor contrário, e "apenas o povo pode conter a prepotência dos nobres" (Silva, 2013, p. 54).$^{46}$

\section{Afirmação trágica: ética da finitude e da grandeza}

Os limites trágicos não levam Maquiavel ao pessimismo fatalista, mas sim a encarar os limites como oportunidade para a grandeza. Como os antigos trágicos, Maquiavel pensava que apesar de sua mortalidade, o homem pode "deixar sua marca no mundo" e alcançar uma forma de "imortalidade”, por meio de suas realizações, que permanecerão além das existências individuais, emprestando sentido e beleza ao mundo e glória para si e para a sua pátria. A ética de Maquiavel passa pela afirmação (trágica) desta vida e 158 deste mundo. Isto pode ser notado na sua preferência pela "mundana" moralidade pagã, que já foi amplamente comentada. ${ }^{47}$ Uma das mais famosas e explícitas destas evidências encontra-se na passagem dos Discursos em que Maquiavel compara a educação e religião dos antigos e dos modernos. Nela, fica clara a sua preferência por uma moralidade que, como a antiga, beatificasse "homens que se cobrissem de gloria mundana", e critica a "nossa religião" que "leva-nos a estimar menos as honras mundanas" e "só tem glorificado os homens mais humildes e contemplativos do que os ativos" (Maquiavel, 2007b, p. 189). Fica explícito que o que Maquiavel valoriza na educação antiga é que ela estimulava a criação de cidadãos fortes, capazes de defender a liberdade e realizar grandes feitos. Por isso, ele enfatiza que na religião antiga "o bem estava na grandeza de animo [ grandezza

\footnotetext{
${ }_{46}$ Nesse sentido, Maquiavel inaugura "a linha de raciocínio que se desenvolveu até a noção de lançar paixões contra paixões” (Hirschman, 2002, p. 54).

${ }^{47}$ Ver: Berlin, 2002; Hulliung, 1983, p. 68; Meinecke, 1962; Parel, 1992, p. 62.
} 
dello animo], na força [fortezza] do corpo e em todas as coisas capazes de tornar fortes os homens" (Maquiavel, 2007b, p. 190). Nesse sentido, a religião assume importância para fornecer bons costumes e fortalecer os cidadãos. Para a saúde da república, ${ }^{48}$ não importa qual é a religião, o importante é que ela estimule a grandezza dello animo dos cidadãos. Se não for possível restaurar o culto pagão, poderia ser elaborada uma nova interpretação do cristianismo, que fosse feita "segundo a virtü" (Maquiavel, 2007b, p. 190).

A ética trágica da finitude e da grandeza aparece na sua preferência pelas intensidades e superação em vez da mera autoconservação. É o que vemos nos momentos em que ele, na dúvida, recomenda a audácia. É o que ocorre no capítulo 25 de $O$ Príncipe. Depois de afirmar que os homens "são felizes enquanto a fortuna e os costumes concordam e, quando discordam, são infelizes", Maquiavel afirma: "acredito que seja melhor ser impetuoso que ponderado, porque a fortuna é mulher" e "ela se deixa vencer mais pelos impetuosos do que por aqueles que friamente procedem; e por isso, como é mulher, sempre é amiga dos jovens, porque são menos prudentes, mais ferozes e comandam-na com mais audácia” (Maquiavel, 2007a, p. 242-243). A conclusão não está demonstrada pelo texto anterior. Por que diante da incerteza seria melhor ser audaz? Afinal, no mesmo capítulo ele escreveu que o Papa Júlio II, que sempre "procedeu em todas as coisas impetuosamente", teria perdido o poder se não tivesse morrido antes, "porque se sobreviessem tempos nos quais fosse necessário proceder por prudência, daí seria a sua ruína: porque nunca teria se desviado dos seus costumes, aos quais a natureza o inclinava" (Maquiavel, 2007a, p. 241). Portanto, Maquiavel não entende que o comportamento audacioso seja sempre o mais adequado do ponto

\footnotetext{
48 Sobre o vocabulário médico da saúde em Maquiavel ver: Araújo, 2013, p. 105; Gilbert, 1951, pp. 53-55; Lucchese, 2009, p. 75.
} 
de vista da eficiência. Entretanto, em cenário de incerteza, recomenda a audácia a priori, "acredito que seja melhor ser impetuoso". ${ }^{49}$

Seu gosto pela intensidade e grandeza também aparece quando sabemos que ele possuía uma preferência pelas repúblicas, mesmo que ele próprio considerasse que nelas existia "mais vida", e, consequentemente, mais conflitos. ${ }^{50}$ Maquiavel não apenas prefere repúblicas como recomenda o modelo "mais vivo" de república: o romano. O faz mesmo depois de escrever que este modelo não seria o mais adequado se o que se busca é ausência de conflito e duração maior (Maquiavel, 2007b, p. 25, 31), mesmo assim ele prefere o modelo romano, visto como mais dinâmico e capaz de alcançar a grandeza. Fica claro que a grandeza da república romana o agrada mais do que a tranquilidade da "sereníssima república" de Veneza. Maquiavel (2007b, p. 29) diz que Roma poderia ter seguido o exemplo de Veneza e Esparta, entretanto, incluiu o povo 160 e forasteiros na política, “o que deu à plebe força, número e infinitas ocasiões para criar tumultos". Ao incluir o povo, Roma fortaleceu o seu próprio exército, em comparação com exércitos formados apenas por nobres. As repúblicas plebeias seriam mais tumultuadas. O tumulto maior, entretanto, não é motivo de reprovação para Maquiavel, porque,

Se o estado romano se tornasse mais tranquilo, decorreria o inconveniente de tornar-se também mais fraco, porque assim lhe era barrado o caminho para chegar à grandeza a que chegou: de tal modo que, se Roma quisesse eliminar as razões dos tumultos, eliminaria também as razões de se

\footnotetext{
49 Se é verdade que os trágicos antigos admiravam a audácia, eles também recomendavam a moderação, a depender das circunstâncias. Em Maquiavel não encontramos um elogio à moderação, o que pode indicar uma diferença entre a sua visão trágica (moderna) e visão trágica antiga.

50 "Mas nas repúblicas há mais vida, maior ódio, mais desejo de vingança" (Maquiavel, 2007a, p. 67).
} 
ampliar. E em todas as coisas humanas quem bem examinar verá que nunca se pode anular um inconveniente sem que surja outro [...]. Por isso, em todas as nossas deliberações, devemos considerar aquilo que apresenta menos inconvenientes e tomá-lo por melhor decisão: porque nunca há nada que seja de todo nítido e sem suspeitas. (Maquiavel, 2007b, p. 29)

Maquiavel termina o argumento com uma reflexão tipicamente trágica: não há nenhuma garantia de que seja possível eliminar todos os inconvenientes, ou que poderia existir um modelo social perfeito em que todos os nossos valores pudessem ser compatibilizados no mesmo grau: sempre existiram e existirão muitas situações de escolhas trágicas nas quais é preciso sacrificar um bem para obter outro, situações de trade-off entre um bem e outro, ou, ainda, situações em que "há males que vêm para bem". Como notou Araújo, "um dos grandes princípios de seu pensamento, repetido à exaustão, é que nenhum acontecimento conveniente ou que produz algo conveniente deixa de ser acompanhado de algum inconveniente" (Araújo, 2013, p. 97). Nas tragédias gregas (e na "visão trágica de mundo"), um conflito tipicamente trágico é justamente entre bem e bem e não entre bem e mal. No exemplo acima citado por Maquiavel há um conflito entre um bem (a paz social) e outro bem (a grandeza). Maquiavel sacrifica parcialmente a paz social ao tolerar um grau maior de conflito para sustentar a grandeza, especialmente em um mundo no qual

todas as coisas humanas estão em movimento e não podem ficar paradas, é preciso que estejam subindo ou descendo; e a muitas coisas a que a razão não nos induz somos induzidos pela necessidade: de tal maneira que, depois de ordenarmos uma república capaz de manter-se sem ampliar-se, se a necessidade a levasse a ampliar-se, seríamos levados a 
destruir os seus fundamentos e a levá-la mais cedo à ruína. (Maquiavel, 2007b, p. 32).

Estas formulações podem ser problemáticas para nós, mas não eram para Maquiavel. ${ }^{51}$ Não é nosso objetivo domesticar Maquiavel para torná-lo palatável às nossas preferências modernas, mas tentar entender o seu pensamento em seus próprios termos.

\section{Considerações finais}

Maquiavel foi um pensador trágico tanto na sua descrição do real (teoria do encontro), quanto na postura que ele recomenda diante desta realidade. Na teoria do encontro, presente em todas as fases da obra de Maquiavel, o real é descrito como uma espécie de Caosmos em devir incessante. Nesta realidade sujeita ao acaso, ocorrem encontros e desencontros que criam corpos mistos mais ou menos duráveis. A 162 virtú - que depende ela própria de diversos encontros - fornece ao agente a capacidade para agarrar a ocasião (Kairós) Occasione) e viver encontros felizes. Entretanto, a virtù tem limites, pois, embora seja possível e necessário usar a prudência, este conhecimento prático é limitado pelo acaso inerente ao real (clinamen/variazione), pela perspectiva e flexibilidade limitada dos indivíduos para mudarem o seu modo de proceder de acordo com a necessidade dos tempos, que estão sempre variando (variazione / devir sem fim). Isso certamente limita o alcance prático do conhecimento sobre a política, enfraquecendo certas aspirações modernas de controle e aplicação da teoria, bem como tende a dissolver o solo sobre o qual se assenta o modo deontológico de fazer teoria política. Entretanto, isso não significa destituir a teoria política de qualquer utilidade prática, pois na teoria (trágica) do encontro de Maquiavel há espaço para a prudência, como

${ }^{51}$ Ver Pocock (1985, p. 570) e Ball (1984, p. 529). 
sabedoria prática e contextual que sabe dos seus próprios limites, como também era para os trágicos antigos. ${ }^{52}$

Nada disso levou Maquiavel a uma visão “pessimista”, ao contrário, como trágico ele era afirmativo e recomendava a vida ativa neste mundo. $\mathrm{O}$ sucesso dos homens de virtù pode ocorrer ou não, mas, ainda em caso de insucesso, existe a possibilidade de caírem com dignidade, de se deleitarem com as ações virtuosas dos outros e até mesmo de rirem de si mesmos e irem "fazer um bom carnaval", como escreveu Maquiavel na carta em que assinou como "historiador, trágico e cômico". A visão trágica de Maquiavel poderia ser considerada um "pessimismo da razão e um otimismo da vontade” (Gramsci, 1947, p. 115), ${ }^{53}$ que não o leva nem à resignação nem a uma negação niilista deste mundo com projeção de algum paraíso no além ou no fim da história. Maquiavel, que amava este mundo e as intensidades, preferiria "ir ao inferno discutir política com os grandes homens da Antiguidade do que ser mandado ao paraíso, para morrer de tédio na companhia dos beatos e dos santos". ${ }^{54}$

\footnotetext{
${ }^{52}$ Sobre a prudência da tradição trágica grega e em Aristóteles ver Aubenque (2003, p. 281).

53 A frase ficou famosa com Gramsci, mas ele citava Romain Rolland, que, por sua vez, havia tomado a frase de um texto de sua amiga Malwida von Meysebug. Malwida era uma das melhores amigas de Nietzsche e viveu com ele por um tempo em Sorrento, na Itália. A frase expõe a visão que Burckhardt e Nietzsche tinham do povo grego da "Era trágica". Nesta visão, segundo Malwida, os gregos teriam combinado "pessimismo da concepção de mundo e otimismo do temperamento" (Montinari, 2002, p. 51).

54 Palavras que Maquiavel teria dito a amigos sobre um sonho que teve nos seus últimos dias de vida. Ver: Martelli, 1971, p. 1203; Ridolfi, 2003, p. 283; Viroli, 2002, p. 17,95 .
} 


\section{Jean Gabriel Castro da Costa}

é doutor pela Universidade de São Paulo e professor de teoria política do Departamento de Sociologia e Ciência Política da Universidade Federal de Santa Catarina.

\section{Bibliografia}

ALTHUSSER, Louis. 1999. Machiavelli and us. London: Verso.

ALTHUSSER, Louis. 2006. Philosophy of the encounter: later writings, 1978-87.

London: Verso.

ARANOVITCH, Patrícia. 2013. O riscontro: considerações sobre a política e a história em Maquiavel. Tempo da Ciência, v. 20, n. 40, pp. 71-90.

ARAÚJO, Cicero R. R. 2013. A forma da república: da constituição mista ao estado. São Paulo: Martins Fontes.

ARISTÓTELES. 1985. A Política. Brasília, DF: Editora Unb.

ARISTÓTELES. 2005. Poética. In: ARISTÓTELES; HORÁCIO;

LONGINO. A Poética Clássica. Tradução: Jaime Bruna. São Paulo:

Cultrix. pp. 17-52.

AUBENQUE, Pierre. 2003. A prudência em Aristóteles. São Paulo: Discurso.

BALABAN, Oded. 1990. The human origins of Fortuna in Machiavelli's thought. History of political thought, v. 11, n. 1, pp. 21-36.

BALL, Terence. 1984. The picaresque prince: reflections on Machiavelli and moral change. Political Theory, v. 12, n. 4, pp. 521-536.

BARON, Hans. 1943. Towards a more positive evaluation of the fifteenthcentury renaissance. Journal of the History of Ideas, v. 4, n. 1, pp. 21-49.

BEDFORD, David ; Workman, Thom. 2001. The tragic reading of the thucydidean tragedy. Review of International Studies, v. 27, n. 1, pp. 51-67.

BERLIN, Isaiah. 2002. A originalidade de Maquiavel. In: BERLIN, Isaiah. Estudos sobre a humanidade: uma antologia de ensaios. São Paulo: Companhia das Letras. pp. 299-348.

BERTELLI, Sergio. 1961. Noterelle machiavelliane. Rivista Storica Italiana,v. 3, pp. 544-557.

BROWN, Alison. 2010a. The return of Lucretius to Renaissance Florence. Cambridge, MA: Harvard University Press.

BROWN, Alison. 2010b. Philosophy and religion in Machiavelli. In:

NAJEMY, John. The Cambridge Companion to Machiavelli. Cambridge:

Cambridge University Press, 2010. pp. 157-172.

BROWN, Alison. 2016a. Lucretian naturalism and the evolution of Machiavelli's ethics. In: NORBROOK, David; HARRISON, Stephen; 
HARDIE, Philip. Lucretius and the Early Modern. Oxford: Oxford University Press. p. 69-89.

BURCKHARDT, Jacob. 2009. A cultura do renascimento na Itália: um ensaio. São Paulo: Companhia das Letras.

CASSIRER, Ernst. 1946. The myth of the state. New Haven: Yale University Press.

CASSIRER, Ernst. 1963. The individual and the cosmos. New York: Barnes \& Noble.

CASTORIADIS, Cornelius. 2002. As encruzilhadas do labirinto II: os dominios do homem. São Paulo: Paz e Terra.

CHABOD, Federico. Machiavelli and the Renaissance. New York, 1965.

CONNOLLY, William. E. 2002. Identity, difference: democratic negotiations of political paradox. Minneapolis: University of Minnesota Press.

CORRINGTON, Robert S. 1997. Nature's religion. Lanham: Rowman and Littlefield.

DELEUZE, Gilles. 2001. Nietzsche e a filosofia. Porto: Rés.

DI MARIA, Salvatore. 1992. Machiavelli's ironic view of history: the Istorie Fiorentine. Renaissance Quarterly, v. 45, n. 2, pp. 248-270.

DI MARIA, Salvatore. 2005. Italian reception of Greek tragedy. In:

GREGORY, Justina (ed.). A companion to Greek tragedy. Malden:

Blackwell. pp. 428-443.

FERRONI, Giulio. 1972. Mutazione e riscontro nel teatro di Machiavelli: e altri saggi sulla commedia del cinquecento. Roma: Bulzoni.

FINCH, Chauncey E. 1960. Machiavelli's copy of Lucretius. The Classical Journal. v. 56, n. 1, p. 29-32.

FLANAGAN, Thomas. 1972. The concept of Fortuna in Machiavelli. In: PAREL, Anthony (ed.). The political calculus: essays on Machiavelli's philosophy. Toronto: University of Toronto Press, 1972. pp. 126-156.

GARIN, Eugenio. 1965. Italian Humanism. Oxford: Harper \& Row.

GILBERT, Felix. 1951. On Machiavelli’s idea of Virtù. Renaissance News, v. 4 , n. 4 .

GILBERT, Felix. 1965. Machiavelli and Guicciardini: politics and history in sixteenth-century Florence. Princeton: Princeton University Press.

GRAMSCI, Antonio. 1947. Lettere dal carcere. 3. ed. Torino: G. Einaudi. GREENBALT, Stephen. 2011. The swerve: how the world became modern. New York: Norton \& Company.

HESÍODO. 1995. Teogonia: a origem dos deuses. São Paulo: Iluminuras. HESÍODO. 1996. Os trabalhos e os dias. São Paulo: Iluminuras.

HIRSCHMAN, Albert. 2001. As paixões e os interesses. Rio de Janeiro: Record. 
HULLIUNG, Mark. 1983. Citizen Machiavelli. Princeton: Princeton University Press.

JAVITCH, Daniel. 1999. The assimilation of Aristotle's Poetics in sixteenthcentury Italy. In: NORTON, Glyn P. (ed.). The Cambridge history of literary criticism: volume III: the Renaissance. Cambridge: Cambridge University Press, 1999. pp. 53-65.

KAHN, Charles H. (ed.). 1979. The art and thought of Heraclitus: a new arrangement and translation of the Fragments with literary and philosophical commentary. Cambridge: Cambridge University Press.

KAHN, Victoria Ann. 1985. Rhetoric, prudence, and skepticism in the Renaissance. Ithaca: Cornell University Press.

KAUFMANN, Walter. 1968. Tragedy and philosophy. Princeton: Princeton University Press.

KOYRÉ, Alexandre. Estudos de história do pensamento científico. São Paulo: Forense Universitária, 1991.

LEFORT, Claude. 2012. Machiavelli in the making. Evanston: Northwestern University Press.

LUCCHESE, Filippo. 2009. Crisis and power: economics, politics and conflict in Machiavelli's political thought. History of Political Thought, v. 30, n. 1, pp. 75-96.

166 LUCRETIUS. 1982. On the nature of things. Cambridge, MA: Harvard University Press.

MACHADO, Roberto. 2006. O nascimento do trágico: de Schiller a Nietzsche. Rio de Janeiro: Zahar.

MACHIAVELLI, Niccolò. 1971. Tutte le opere. Firenze: Sansoni.

MANSFIELD, Harvey C. Machiavelli's virtue. Chicago: University of Chicago Press, 1996.

MAQUIAVEL, Nicolau . 2007a. O Príncipe. São Paulo: Hedra.

MAQUIAVEL, Nicolau. 1998. História de Florença. 2. ed. São Paulo: Musa.

MAQUIAVEL, Nicolau. 2003. A vida de Castruccio Castracani da Lucca.

Porto: Porto Editora.

MAQUIAVEL, Nicolau. 2004. A Mandrágora. São Paulo: Peixoto Neto. (Os grandes dramaturgos)

MAQUIAVEL, Nicolau. 2007b. Discursos sobre a primeira década de Tito Livio. São Paulo: Martins Fontes.

MAQUIAVEL, Nicolau. 2011. Di Fortuna e Dell' Occasione. Cadernos de Ética e Filosofia Política, v. 18, n. 1, pp. 231-247.

MAQUIAVEL, Nicolau. 2015. Ghiribizzi ao Soderini. Cadernos Espinosanos, n. 32, pp. 267-278. 
MARTINEZ, Ronald. 1993. Benefit of absence: machiavellian valediction in Clizia. In: ASCOLI, Albert Russell; KAHN, Victoria Ann. Machiavelli and the discourse of literature. Ithaca: Cornell University Press.

pp. 117-144.

MARTINEZ, Ronald. 2000. Tragic Machiavelli. In: SULLIVAN, Vickie B. (ed.). The comedy and tragedy of Machiavelli. New Haven: Yale University Press. pp. 102-119.

MEINECKE, Friedrich. 1962. Machiavellism: the doctrine of raison d'etat and its place in modern history. New Haven: Yale University Press.

MERRILL, William A. 1926. The Italian manuscripts of Lucretius. Berkeley: University of California Press.

MONTINARI, Mazzino. 2002. Equívocos marxistas. Cadernos Nietzsche, 12, pp. 33-52.

NAJEMY, John M. 1993. Between friends: discourses of power and desire in the Machiavelli-Vettori letters of 1513-1515. Princeton: Princeton University Press.

NIETZSCHE, Friedrich. 1992. O nascimento da tragédia ou helenismo e pessimismo. São Paulo: Companhia das Letras.

NIETZSCHE, Friedrich. 2005. Gaia ciência. São Paulo: Companhia das Letras.

NIETZSCHE, Friedrich. 2008. Ecce homo. São Paulo: Companhia das Letras.

NIETZSCHE, Friedrich. 2011. Assim falou Zaratustra. São Paulo: Companhia das Letras.

NORBROOK, David; Harrison, Stephen; Hardie, Philip. 2016. Lucretius and the early modern. Oxford: Oxford University Press.

PALMER, Ada. 2012. Reading Lucretius in the Renaissance. Journal of the History of Ideas. v. 73, n. 3, pp. 395-416.

PALMER, Ada. 2014. Reading Lucretius in the Renaissance. Cambridge, MA: Harvard University Press.

PAREL, Anthony. 1992. The machiavellian cosmos. New Haven: Yale University Press.

PITKIN, Hanna Fenichel. Fortune is a woman: gender and politics in the thought of Niccolò Machiavelli. Berkeley: University of California Press, 1984.

PLATÃO. 2006. A República. São Paulo: Martins Fontes.

POCOCK, John G. A. 1985. "Machiavelli in the liberal cosmos". Political Theory, v. 13, n. 4, pp. 559-574.

POLÍBIO. História. Brasília, DF: Editora UnB, 1996. 
PRIGOGINE, Ilya. 1996. O fim das certezas: tempo, caos e as leis da natureza. São Paulo: Editora Unesp.

RAHE, Paul. 1995. Thomas Jefferson's machiavellian political science. The Review of Politics, v. 57, n. 3, pp. 449-481.

RAHE, Paul. 2007. In the shadow of Lucretius: the epicurean foundations of Machiavelli's political thought. History of Political Thought, v. 28, n. 1, pp. 30-55.

RIDOLFI, Roberto. 2003. Biografia de Nicolau Maquiavel. São Paulo: Musa. ROSSET, Clément. Lógica do pior. Rio de Janeiro: Espaço e Tempo, 1989.

SILVA, Ricardo. 2013. Da honra ao patrimônio: conflito social e instituições políticas nos Discorsi de Maquiavel. Revista Brasileira de Ciência Política, nำ12, pp. 43-66.

SKINNER, Quentin. 1988. Maquiavel. São Paulo: Brasiliense.

SKINNER, Quentin. 1996. As fundações do pensamento político moderno. São Paulo: Companhia das Letras.

SÓFOCLES. 1998. Trilogia Tebana. Rio de Janeiro: Jorge Zahar.

SQUAROTTI, Giorgio Bàrberi. 1966. La forma tragica del "principe" e altri saggi sul Machiavelli. Firenze: L. S. Olschki.

STEINER, George. 2006. A morte da tragédia. São Paulo: Perspectiva.

STRAUSS, Leo. 1958. Thoughts on Machiavelli. Chicago: University of Chicago Press.

TARLTON, Charles D. 1968. The Symbolism of Redemption and the Exorcism of Fortune in Machiavelli's Prince. The Review of Politics, v. 30, n. 3, pp. 332-348.

VACANO, Diego A. von. 2007. The art of power: Machiavelli, Nietzsche, and the making of aesthetic political theory. Plymouth, UK: Lexington Books.

VIROLI, Maurizio. 1998. Machiavelli. Oxford University Press.

VIROLI, Maurizio. 2002. O sorriso de Nicolau. São Paulo: Estação Liberdade.

WOOD, Neal. 1972. Machiavelli's humanism of action. In: PAREL, Anthony (ed.). The political calculus: essays on Machiavelli's philosophy. Toronto: University of Toronto Press.

YORK, Michael. 2003. Pagan theology: paganism as a world religion. New York: New York University Press. 


\section{MAQUIAVEL, PENSADOR TRÁGICO}

\section{JEAN CASTRO DA COSTA}

Resumo: $\mathrm{O}$ artigo defende que Maquiavel foi um pensador trágico. Após breve introdução sobre os aspectos centrais de uma visão trágica de mundo, apresento, na primeira seção, evidências de que o autor de $O$ Príncipe poderia ter chegado a esta visão a partir das fontes disponíveis no seu contexto intelectual. Entre estas fontes, destaco a recepção do livro De Rerum Natura, de Lucrécio, na Florença renascentista. Na segunda seção, procuro explicitar a visão trágica do cosmos presente nos textos de Maquiavel, com ênfase na sua teoria do encontro (riscontro). Na terceira seção, defendo que diante deste cosmos trágico, Maquiavel coloca-se em favor de uma afirmação trágica, que aposta na virtù mesmo sabendo que seu sucesso depende de um encontro feliz com a Fortuna, que pode acontecer ou não. Palavras-chave: Maquiavel; Trágico; Teoria do Encontro; Lucrécio.

\section{MACHIAVELLI, TRAGIC THINKER}

Abstract: The article argues that Machiavelli was a tragic thinker. After a brief introduction to the key aspects of a tragic view of the world, I offer, in the first section, evidence that the author of The Prince could have reached this view from the sources available to his intellectual circle. Among these sources, I focus on Lucretius' book De Rerum Natura, and its reception in Renaissance Florence. In the second section, I show the tragic view of the cosmos in Machiavelli's texts, with an emphasis on his theory of the encounter (riscontro). In the third section, I argue that faced with this tragic cosmos, Machiavelli defends a tragic affirmation that wagers on virtù, knowing that success depends on a happy encounter with Fortune, which may or may not happen.

Keywords: Machiavelli; Tragic; Theory of the Encounter; Lucretius.

Recebido: 10/06/2016

Aprovado: 11/04/2018 